\section{No Border}

\author{
巻／頭／言
}

今, 生物物理若手の会主催の夏の学校に来ている.いつにも増 して主催者の意気込がヒシヒシと伝わる. 夏の学校って学生やポ スドクでないとなかなか行く機会が無いと思うけど, もともと生 物物理学会って夏の学校からスタートし，その後で年会を開く一 人前（?）の学会になったと聞く。そらいった意味では，今の夏 の学校にも次の新しい流れを生み出す孵卵器としての役割もある かもしれない*1. 今年のスピーカーは生物物理学だけでなく, 計 算機工学や応用数学などで活躍している研究者も多かった．そも そも今年のテーマはN No Border とのこと. これはまったく同感 学問の境界，そんなもの気にする必要なんて全然無い。ときどき 「生物物理って大学に学科も無ければ, discipline としても確立し ていない」と自嘲気味の意見を聞く，実際，「生物物理学専攻」っ てほとんど無くて，たいていの会員は生物化学や物理，化学系の 専攻に所属している，そのため「標準的教科書が無い」といら弊 害はあって，それはそれでけっこう問題なんだけど*2，学会自体 の性質としては「それでイイじゃん」って思う。私が感じる生物 物理学会の良さって，まさにこの「なんでもあり」なとこである. 私が生物物理に参加するよらになってからも MEMS や非平衡物 理の若手が参加するようになり，そのうち何人かは若手奨励賞を 受賞して学会に定着している. 研究領域のBorder に対して鈍感 といらか抢抢らかなところが，この学会のダイナミズムを生み出 す1つの原動力だろう.

自分の研究に関しても, 研究分野の境界とか正直どーでもい い、打もろいことをトコトンやるだけである。 もちろんプロの学 者としては「成果を挙げなきゃ!」なので安易には別領域に踏み 込めないんだけど，No Borderってまさにずっと私の気分．先に 言われちゃった感はあるけど，まっ良いか，いただいちゃおうこ のフレーズ.

野地博行, Hiroyuki NOJI

東京大学工学研究科応用化学, 教授

*1 といっても彼らにはその自覚は無いだろうし必要も無いんだけどね

*2「生物物理」Vol. 53 No. 3 高田さんの巻頭言を参照のこと. 